\title{
Earnings Management: A Literature Review
}

\author{
Shuang Gao \\ Harbin institute of technology Shenzhen \\ Guangdong, China
}

\author{
Jie Gao* \\ Harbin institute of technology Shenzhen \\ Guangdong,China
}

\begin{abstract}
Earnings management is the one of the classic topics in accounting field. Most of the extant studies focus on accrual-based earnings management. Recent years, real activities earnings management has received more attention from researchers. Exploration of earnings management behavior can extend the current limited earnings management studies, helping to improve the corporate governance, improving the quality of earnings information, promoting the healthy and orderly development of the securities market. With the aim to provide guidance for corporate governance and future research, firstly, this study dealt with the existing research literature of earnings management on the incentives, means and economic consequences, measure methods, then made comparative analysis of accrual-based and real activities earnings management. Finally this article summarized the main research results and limitations of the current earnings management, providing direction to extend our real earnings management research and improve the quality of the earnings quality.
\end{abstract}

Keywords-earnings management, manipulation means, incentives, economic results.

\section{INTRODUCTION}

Managers usually use earnings management to achieve their business objectives (Roychowdhury, 2006; Cohen et al., 2008; Zang, 2012). Earnings management is divided into accrued items surplus management and real earnings management activities. Accrued-based earnings management is achieved through the adoption of different accounting methods, while real activities earnings management to be achieved by manipulating the enterprises real activities. No matter what kind of earnings management was used, it will generate effects on the firm performance; what's more, real activities manipulation management will cause more significant influence on firm value. Extant studies of real earnings management mainly focus on earnings management means identification, influencing factors, economic results, managers' choices between accrual-based and real activities manipulation earnings management, and so on. This study reviews the existing research on earnings management comprehensively. The second part reviews related research on earnings management approach and incentives, the third part reviews the related research on economic consequences and influence factors of earnings management, the fourth part reviews relationship between accrued-based and the real activities manipulation management. Finally, this article summarizes the main research results and limitations of the current research.

\section{EARNINGS MANAGEMENT INCENTIVES AND MEANS}

Theory and evidence indicate that managers' concerns over current performance motivate them to engage in manipulating

* Correspondence author. This study is funded by the postgraduate education reform research project of Harbin Institute of Technology (No. JGYJ-201543) current period earnings at the expense of future period earnings (e.g., Stein,1989; Fudenburg and Tirole, 1995; Pauwels et al., 2004; Graham et al., 2005; Rodriguez-Perez and van Hemmen, 2010). Given the inherent risk of stock-based compensation incentives, earnings management is driven by managers with the intention of obtaining some private gain at shareholders' expense (Schipper, 1989). One of the fundamental drivers of earnings management is the pressure on managers to deliver short-term performance that is used in contracting and firm valuation. Balasubramanyan et al. (2013) investigated the change of earnings management in 27 countries over the period 2005-2010 and found an increase of earnings management directed to the manipulation of book value of equity and regulatory capital. A recent survey study, Dichev, Graham, Harvey, and Rajgopal (2013), concludes that " about 20 percent of firms manage earnings to misrepresent economic performance, and for such firms 10 percent of EPS is typically managed. Using a different research methodology, Dyck, Morse, and Zingales (2013) also conclude that earnings management and accounting frauds are prevalent. The motivations for altering financial information vary from meeting regulatory thresholds and analysts' forecasts, to smoothing managerial compensation and obtaining desirable stock valuations in capital markets (Dechow \& Skinner, 2000; Healy, Hutton, \& Palepu, 1999; Lo, 2008). Recently, the literature starts to examine the effect of CFOs on earnings quality, while prior studies tend to focus on the management team as a whole or CEOs. Ge, Matsumoto, and Zhang (2011) find that CFOs are responsible for various accounting choices, such as discretionary accruals, the likelihood of meeting or just beating earnings expectations, and the likelihood of restatements. Bedard, R. Hoitash, and U. Hoitash (2014) find that firms with CFOs who sit on their own board exhibit higher reporting quality (e.g., lower likelihood of internal control weaknesses, lower likelihood of restatements and higher accruals quality). Jiang et al. (2010) find that the magnitude of accruals and the likelihood of meeting or just beating analysts' forecasts are more sensitive to CFOs' than to CEOs' equity incentives in the pre-SOX period. Feng et al. (2011) conclude that the direct financial gain is not the main motivation for CFOs to be involved in earnings manipulation. Rather, CFOs likely succumb to powerful CEOs' pressure to manipulate financial statements. Earnings management is divided into accruals-based management and real earnings management activities. Firms manipulate accruals by exploiting the flexibility of accounting rules to temporarily 'mask' true firm performance (Boonlert-U-Thai, Meek, \& Nabar, 2006; Dechow\& Skinner, 2000). Managers intervene in the financial reporting process by exercising discretion and judgment regarding accounting choices. Qiang Cheng and Terry D. Warfield (2005) find that managers with high equity incentives 
are more likely to report earnings that meet or just beat analysts' forecasts. Also, managers with high equity incentives are more likely to report earnings that meet or just beat analysts' forecasts. Bergstresser and Philippon (2006) show that incentives derived from stock-based compensations motivate managers to engage in AEM.

Extensive research has documented that Chinese listed firms use discretion in the accrual accounting process to manage their earnings information. The CSRC requires firms to report positive earnings (return on equity) for three consecutive years, and Chen and Yuan(2004) and Haw, Qi, Wu, and $\mathrm{Wu}$ (2005) show the use of discretionary accruals to meet this specific regulatory threshold for maintaining listing status, qualifying for IPOs and rights issues or avoiding delisting or trading restrictions (special treatment). In addition, controlling shareholders tunnel resources or prop up earnings in the form of related party transactions, transfer pricing, or corporate loans and subsidies from the local governments to beat regulatory benchmarks (Chen et al., 2008; Cheng, Aerts, \& Jorissen, 2010; Jian \& Wong, 2010; Jiang \& Wang, 2008;Liu \& Lu, 2004; Yu et al., 2006).

There are studies showing that managers will alter the timing or structuring of transactions, investment, and allocation of resources to boost accounting earnings in the current periods, including accelerating the sales, changing the schedule, delaying development costs and other methods (Dechow and Skinner, 2000). It has a direct effect on operating activities and cash flow. At present, the most classic definition of earnings management bout the real activities are proposed by Roychowdhury (2006): "it is an enterprise's economic activities which managers in order to mislead the users of the information and build the painstakingly, phasing deviation from normal business operations ". Later, some scholars also reached the same conclusion through empirical studies that managers would manipulate the real activities to achieve their goals (Bens et al., 2002200; Cohen and Zarowin, 2010; Kim et al., 2010). Managers will reduce R\&D spending to boost the company's short-term performance (Bushee 1998; Cheng, 2004). When income is not achieve at desired goal, managers can increase current earnings by selling fixed assets and securities to increase current earnings (might, D., t. Inoue, and w. Thomas, 2003). Graham et al. (2005) found that $80 \%$ of managers achieve the profit targets of the current period by reducing $\mathrm{R} \& \mathrm{D}$, advertising, upkeep and postpone the new projects. Research has shown that managers will use $R \& D$ spending to buy back shares to avoid diluted earnings per share, to achieve the short-term goal (Bens et al., 2003; Hribar et al., 2006). Managers can manipulate COGS expense in any period by overproducing to spread fixed overhead costs over a larger number of units as long as the reduction in per-unit cost is not offset by inventory holding costs or any increase in marginal cost in the current period. Thomas and Zhang (2002)'s study shows that enterprises engage in excessive production enterprises to achieve business objectives. Roychowdhury (2006) argues that management mainly from sales manipulation (e.g., ease restrictions on the conditions of sale, credit conditions, increase sales, discount, etc.), production control(such as using the scale effect mass production in order to reduce the unit product cost), the control of discretionary expenditure(such as narrowing the research and development costs, advertising costs and maintenance costs, etc.) earnings management three aspects to carry on the real activities manipulation. Later, many scholars research of earnings management on real activities are all around these three ways (Chi, w. Lisic, 1. 1., \& Pevzner, m., 2011, li, jun-rui zhang, 2008, 2009).

\section{EARNINGS MANAGEMENT INFLUENCING FACTORS AND ECONOMIC CONSEQUENCES}

Francis et al. (2004), Gray et al. (2009) and Aboody et al. (2005) report that AEM increases the cost of equity; Francis et al. (2005) and Bharath et al. (2008) document that AEM also increases the cost of debt. In contrast, Mc Innis (2010) argues that earnings smoothing does not affect the cost of equity. Bhojraj et al (2009) found that companies which reach predicted targets by earnings management have worse management and stock market performance in the next three years than companies which not use earnings management and not reach predicted targets. Filip and Raffournier (2012) suggest an earnings management decrease over the crisis years (e.g. 2008-2009) with respect to the expansion period (e.g. 2006-2007). Real activities manipulation management could weaken the company's future performance, reducing the company's long-term value, also increasing the long-term cost of the shareholders of a company (Roychowdhury, 2006; Cohen et al., 2008; Cohen and Zarowin, 2010), such as sales discount and easy credit conditions will reduce the sales during the future; Reducing discretionary spending, and put investment to excessive production of inventory which there is no need (Roychowdhury, 2006; Gupta et al., 2010), leading in increases at inventory costs as well as reducing the future earnings. Li, jun-rui zhang $(2008,2009)$ from the production control, cost control and sales control three aspects to study, finding that using real activities earnings management lead in a significant reduction in its future performance. Kim et al. (2009) 'study shows that, compared with accrued items earnings management, the real surplus management activities make company estimates of future value have greater uncertainty. However, studies have shown that the consequences of earnings management through the real activities are not always negative. Through the realization of surplus threshold, making for the company's capital market investor's confidence, and make the company show a good performance in the stock market (Graham, 2005). Taylor \& Xu (2010) proposed the implementation of real earnings management of the company is to cater to or breakthrough control analyst earnings expectations and the implementation of practical activities, their research results show that the real activities of earnings management of the enterprise did not have a significant negative impact on future performance. Gunny (2010) found that companies which just return the earnings benchmark by real earnings management activities has a better operating performance over the next three years than companies which didn't use earnings management and not reach the earnings benchmark, he made the interpretation of the results using signaling theory, thinking the enterprises' real activities earnings management gives a positive signal to the market, offsetting the adverse effect. Real activities manipulation management is potentially more costly for firms 
in the long run than accruals-based earnings management (Cohen and Zarowin, 2010).

With respect to the key factor constraining earnings management, extensive previous research suggests that good corporate governance can limit firms' opportunistic behaviors, improving the information environment and the quality of earnings. Effective boards can discipline top management who pursue aggressive earnings strategies to manipulate accruals, thereby reducing possible costly external consequences (Hazarika et al., 2012). Armstrong et al. (2012) document an improvement in the information environment as evident in the decrease of information asymmetry and increased financial statement in formativeness on the passing of anti-takeover laws, which has an exogenous effect on the corporate control market. Liu and $\mathrm{Lu}$ (2007) document that inefficient corporate governance as a result of principal-agent conflicts increases earnings management in the form of tunneling. Both Ding, Zhang, and Zhang (2007) and Wang and Yung (2011) also find that listed firms with private controlling ownership demonstrate a higher level of accrual-based earnings management than state-controlled firms, since private-listed firms face a tougher environment to raise capital and only have minimal state support. Liu and Tian (2012) show an improvement in corporate governance after the SSSREF has reduced both tunneling and excess leverage by controlling shareholders with excess control rights. Later, Kuo et al. (2014) find that firms' use of discretionary accruals was constrained, and they have consequently shifted to less detectable and under-scrutinized real earnings activities after the split share structure reform.

\section{EARnings Management MEASUREMENT MODEL}

\section{Accrual-based earnings management}

Daniel A. Cohen and Paul Zarowin use a cross-sectional model to calculate discretionary accruals, where for each year we estimate the model for every industry classified by its 2digit SIC code. Thus, our approach partially controls for industry-wide changes in economic conditions that affect total accruals while allowing the coefficients to vary across time (Kasznik, 1999; DeFond and Jiambalvo, 1994). Their primary model for estimating discretionary accruals is based on the following cross-sectional model estimated for each 2 digit SICyear grouping as follows:

$$
\frac{T A_{i t}}{\text { Assetsit }-1}=k 1 \frac{1}{\text { Assets } i, t-1_{1}}+k 2 \frac{\Delta S A L E S_{i t}}{\text { Asset }_{i, t-1}}+k 3 \frac{P P E_{i t}}{\text { Assetsi }, t-1_{1}}+\varepsilon_{i t}
$$

where, for fiscal year $t$ and firm $i$, TA represents the total accruals defined as $\mathrm{TA}_{\mathrm{it}}=\mathrm{EBXI}_{\mathrm{it}}-\mathrm{CFO}_{\mathrm{it}}$. where is the earnings before extraordinary items and discontinued operations and $\mathrm{CFO}$ is the operating cash flows taken from the statement of cash flows Asset ${ }_{i t-1}$ represents total assets, $\triangle$ SALES $_{\text {it }}$ is the change in revenues from the preceding year, and $\mathrm{PPE}_{\mathrm{it}}$ is the gross value of property, plant and equipment.

The coefficient estimates from (1) are used to estimate the firm-specific normal accruals $\left(\mathrm{NA}_{\mathrm{it}}\right)$ for our sample firms.

$$
N A_{i t}=k 1 \frac{1}{\text { Assets }_{i, t-1}}+k 2 \frac{\Delta S A L E S_{i t}}{\text { Assets }_{i, t-1}}+k 3 \frac{P P E_{i t}}{\text { Assetsit }-1_{1}}
$$

Where measurement of discretionary accruals is the difference between total accruals and the fitted normal accruals, defined as $\mathrm{DA}_{\mathrm{it}}=\left(\mathrm{TA}_{\mathrm{it}} /\right.$ Assets $\left._{\mathrm{i}, \mathrm{t}-1}\right)-\mathrm{NA}_{\mathrm{it}}$

\section{Real activities manipulation earnings management}

According to Roychowdhury (2006), real activities manipulation earnings management is achieved mainly by three means. They are sales, production and discretionary expenditure manipulation. These three means could be measured by abnormal operating activities net cash flow, abnormal product cost and abnormal discretionary expenses respectively.

Estimate the normal operating activities cash flow

$$
\frac{\text { CFO }_{i t}}{\text { Asset }_{i, t-1}}=k 1 \frac{1}{{\text { Assets } i_{i, t-1}}_{1}}+k 2 \frac{\text { SALES }_{i t}}{\text { Assetsi }, t-1_{1}}+k 3 \frac{\Delta S A L E S_{i t}}{\text { Assets }_{i, t-1}}+\varepsilon_{i t}
$$

Among them, the $\mathrm{CFO}_{i t}$ is Cash flow from operating activities of company $i$ in year $t$, Asset $_{i, t-1}$ is the total assets of company $i$ in year $t-1, S A L E S_{i t}$ is the sales of company $i$ in year $t, \triangle S A L E S_{i t}=S A L E S_{t}-S A L E S_{t-1 N}$, subtracting the normal operating activities cash flow with the actual operating activities cash flow, to calculate the abnormal operating activities cash flow $R \_C F O_{i t}$ of company $i$ in year $t$, and then calculate the average abnormal operating activities cash flow $R \_C F O_{i}$ of company $i$ during sample as average sales manipulation level of company $i$.

Estimate the normal production cost

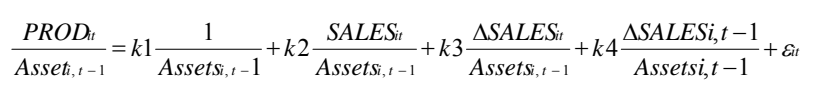

Among them, $P R O D_{i}$ is the sum of variation of production cost, operation cost and inventory cost of company $i$ in year $t$, in the same way, we calculate $R M \_P R O D_{i t}$ and $R M \_P R O D_{i}$ as average production manipulation level of company $i$.

Estimate the normal discretionary expenses

$$
\frac{\text { DISX }_{i t}}{\text { Asset }_{i, t-1}}=k 1 \frac{1}{\text { Asset }_{i, t-1}}+k 2 \frac{\text { SALES }_{i, t-1}}{\text { Asset }_{i, t-1}}+\varepsilon_{i t}
$$

Among them, DISEXP $P_{i t}$ is the discretionary expenses of company $i$ in year $t$, the sum of the sales cost and management cost. In the same way, calculate RM_DISEXP it and $R M \_D I S E X P_{i}$ as average discretionary expenses level.

Considering that company may use three earnings management at the same time, therefore, refer to the method of Li Zengfu, establishing comprehensive indicators $\mathrm{RM}_{\mathrm{t}}$.

$$
R M_{\mathrm{t}}=R M_{-} P R O D_{t}-R M_{-} C F O_{t}-R M_{-} D I S E X P_{t}
$$

\section{RELATIONSHIP BETWEEN ACCRUED-BASED AND THE REAL ACTIVITIES MANIPULATION MANAGEMENT}

Schipper(1989) put forward the viewpoint of real activities manipulation, thinking that real activities manipulation, like accrued items earnings management, are all managers for their personal interests and behavior intervention in the financial report. Previous studies mostly tend to be accrued items earnings management, but with the increase of regulation, especially the sarbanes-oxley issued after the manipulation of real activities manipulation became managers surplus better 
choice (Tan, Jamal, 2006; Cohen et al., 2008). Existing literature documents that real manipulation is more likely when accounting practices are under greater scrutiny. Cohen, Dey, and Lys (2008) find greater incidence of real earnings management in the period following the implementation of the Sarbanes-Oxley Act (SOX) in 2002, which sought to limit questionable accrual choices. This evidence is consistent with the analytical results of Ewert and Wagenhofer (2005), who demonstrate that managers switch from AEM to REM in an environment of tightened accounting standards or more stringent enforcement. Cohen and Zarowin (2010) and Zang (2012) report that firms whose auditors are likely to be more vigilant with respect to accounting choices engage more in real activities manipulation management. Further, existing literature suggests that the presence of institutional investors constrains real activities earnings management (Zang 2012). Cohen and Zarowin (2010) investigates the behaviors of REM and AEM around seasoned equity offerings (SEO), that is, during the period in which managers have relatively high incentives to artificially inflate current period earnings. They find that earnings manipulation via both accruals and real activities is associated with poor future earnings performance, although the association is stronger when real activities are involved. Zang (2012) investigates the sequentiality and substitutive relation between AEM and REM. She finds that managers make REM decisions during the fiscal year before making AEM decisions around the end of the accounting period. Her analysis further shows that while managers use both AEM and REM to manage reported earnings; these two methods are substitutes for each other. Matsuura(2008) also finds that these two earnings management methods are sequential but complementary in income smoothing. The preceding results, taken as a whole, suggest that managers take into account potential costs associated with their choice between AEM and REM when deciding upon earnings management strategies.

\section{CONCLUSION}

Studies about earnings management is in a stage of vigorous development. Research on the motivation of earnings management is relatively rich, for example, meeting earnings benchmarks, obtaining stock-based compensation and desirable stock valuations, pressure related to job security, and so on. Earnings management is achieved by two means, accruals-based management and real earnings management activities. The former is manipulated by accounting method, and the latter is manipulation real activities, mainly including sales, production cost and discretionary expenses.

Most research demonstrates that earnings management led to negative economic consequences. Studies also find that real activities manipulation management imposes more serious consequences on firms than accrual-based earnings management. Existing research on the analysis of the economic consequences of earnings management is not very comprehensive, some studies even generate contradictory results, so further research is necessary to dig deeper to find out the reasons. Most research results are based on data in US. Future research could investigate further the effect of institutional characteristic on the behavior of earnings management.

\section{REFERENCES}

[1] Cohen, D., A. Dey, and T. Lys. Real and accrual-based earnings management in the pre- and post-Sarbanes-Oxley period $[\mathrm{J}]$. The Accounting Review, 2008, 83 (3): 757-787.

[2] Cohen, D., and P. Zarowin. Accrual-based and real earnings management activities around seasoned equity offerings $[\mathrm{J}]$. Journal of Accounting and Economics, 2010, 50 (1): 2-19.

[3] Gunny, K. A. The relation between earnings management using real activities manipulation and future performance: Evidence from meeting earnings benchmarks [J]. Contemporary Accounting Research, 2010, 27 (3): $855-888$.

[4] Matsumoto, D. Management's incentives to avoid negative earnings surprises.Accounting Review, 2002.77 (3): 483-514.

[5] Roychowdhury, S. Manipulation of earnings through the management of real activities that affect cash flow from operations, Dissertation, University of Rochester. 2004

[6] Roychowdhury, S. Earnings management through real activities manipulation [J]. Journal of Accounting and Economics, 2006, 42 (3): 335-370.

[7] Taylor, G.K., Xu, R.Z.Consequences of real earning management operating performance $[\mathrm{J}]$. Research in Accounting Regulation, 2010, 22:128-132

[8] Zang, A. Y. Evidence on the trade-off between real activities manipulation and accrual-based earnings management $[\mathrm{J}]$. The Accounting Review, 2012, 87(2): 675-703. 